\title{
PENGARUH KEBIJAKAN DIVIDEN, LEVERAGE, EARNING VOLATILITY, DAN VOLUME PERDAGANGAN TERHADAP VOLATILITAS HARGA SAHAM PADA PERUSAHAAN SEKTOR FINANCE YANG TERDAFTAR DI BEI TAHUN 2014-2018
}

\author{
Ayuda Rizkya Utami \\ Universitas Negeri Surabaya \\ ayudarizkyautami@gmail.com \\ Purwohandoko \\ Universitas Negeri Surabaya \\ purwohandoko@unesa.ac.id
}

\begin{abstract}
This study aims to determine the effect of dividend policy, leverage, earning volatility, and trading volume on stock price volatility. This research is causality and uses quantitative data obtained by the purposive sampling method. There are 17 companies as research samples. The data analysis technique used is multiple linear regression. This study's object is a company listed in the Finance sector in the Indonesia Stock Exchange for the period 2014 - 2018. The data used from financial reports, annual reports, and a summary of listed companies' performance. The research analysis method uses a multiple linear regression with IBM SPSS version 25 software. The study results found that dividend payout ratio and dividend yield were a significant positive effect on stock price volatility. While leverage, earning volatility, and trading volume does not affect stock price volatility.
\end{abstract}

Keywords: dividend policy; earning volatility; leverage; stock price volatility; trading volume.

\section{PENDAHULUAN}

Pasar modal menjadi salah satu hal yang berperan penting bagi pergerakan ekonomi di suatu negara. Hal ini dikarenakan fungsi dari pasar modal sebagai penyedia tempat dan fasilitas perantara pihak yang memiliki anggaran berlebih (investor) dengan pihak yang mengharapkan dana, yang dilakukan dengan menjualbelikan saham (Tandelilin, 2010:26). Di Indonesia, pasar modal mengalami peningkatan yang signifikan dari periode ke periode. Dari data yang diambil pada tahun 2014, jumlah Singel Investor Identification (SID) yang terdaftar sebanyak 364.465 SID dan mengalami peningkatan pada tahun 2015 sebanyak 19,10\% menjadi 434.107 SID. Di tahun 2016, mengalami peningkatan yang cukup tinggi sebesar 105,97\% menjadi 894.116 di mana pada tahun 2016 ini merupakan kenaikan tertinggi dari periode 2014-2018. Pada tahun 2017, jumlah SID meningkat sebesar 25,56\% menjadi 1.122.668, kemudian pada tahun 2018 SID meningkat sebesar 44,06\% menjadi 1.617 .367 SID (ksei.co.id, 2018).

Dengan berkembangnya pasar modal yang pesat ini memberikan dampak yang besar bagi sensitifitas pasar modal. Maka dari itu, penting bagi investor untuk lebih berhati-hati dalam pengambilan keputusan berinvestasi. Dalam membuat keputusan ada dua faktor yang biasanya dilihat oleh investor yakni, faktor pendapatan dan tingkat risiko (Rohmawati, 2017). Pendapatan yang diharapkan oleh para pemegang saham berupa dividen ataupun capital gain. Dividen adalah pemberian laba kepada investor yang dilakukan oleh perusahaan yang telah menghasilkan laba dan diberikan setelah adanya persetujuan dari investor saat pelaksanaan Rapat Umum Pemegang Saham (RUPS) (Lestari \& Permatasari, 2016). Capital gain adalah nilai perbedaan harga pembelian saham dan harga jual saham, di mana harga jual memiliki nilai yang lebih tinggi daripada harga beli (Andes et al., 2017).

Dalam mengambil keputusan di pasar modal, selain melihat faktor risk and return investor juga harus memiliki informasi yang relevan. Informasi dapat berupa hal-hal yang berkaitan dengan perusahaan, baik mengenai harga maupun kinerja dari suatu perusahaan. Informasi tersebut, dapat memengaruhi investor untuk berinvestasi di perusahaan ataupun menjual sahamnya, hal tersebut dapat memicu 
Ayuda Rizkya Utami \& Purwohandoko. Pengaruh Kebijakan Dividen, Leverage, Earning Volatility, dan Volume Perdagangan terhadap Volatilitas Harga Saham pada Perusahaan Sektor Finance yang Terdaftar di BEI Tahun 2014-2018

pergerakan dari nilai harga saham (Jannah \& Haridhi, 2016). Dari penjelasan tersebut dapat memicu volatilitas harga saham.

Volatilitas harga saham yaitu harga saham yang tidak stabil yang disebabkan oleh pemberitaan yang ada di pasar modal. Volatilitas harga saham menjadi suatu hal yang diperhatikan investor dalam pasar modal karena, dapat menjadi tumpuan dalam menentukan strategi berinvestasi (Dewi \& Suaryana, 2016). Hal ini karena, volatilitas harga saham dapat menjelaskan kepada investor tentang tingkat risiko yang didapat. Seorang investor akan mendapat resiko yang semakin tinggi jika volatilitas harga saham yang bertambah tinggi. Seorang trader jangka pendek biasanya lebih menyukai tingkat volatilitas yang besar untuk mendapatkan return berupa capital gain yang tinggi. Sebaliknya trader jangka panjang lebih menyukai nilai volatilitas yang rendah untuk memperoleh kestabilan nilai return (Priana \& Muliartha, 2017).

Pada tahun 2018, volatilitas pasar harga saham lokal atau Indeks Harga Saham Gabungan (IHSG) cukup tinggi. Indeks Harga Saham Gabungan (IHSG) sempat menduduki level tertinggi sepanjang masa di angka 6.689,29 pada Februari 2018. Setelah itu, IHSG kembali terpuruk di posisi 5.821,81 (Investasi.kontan.co.id, 2018).

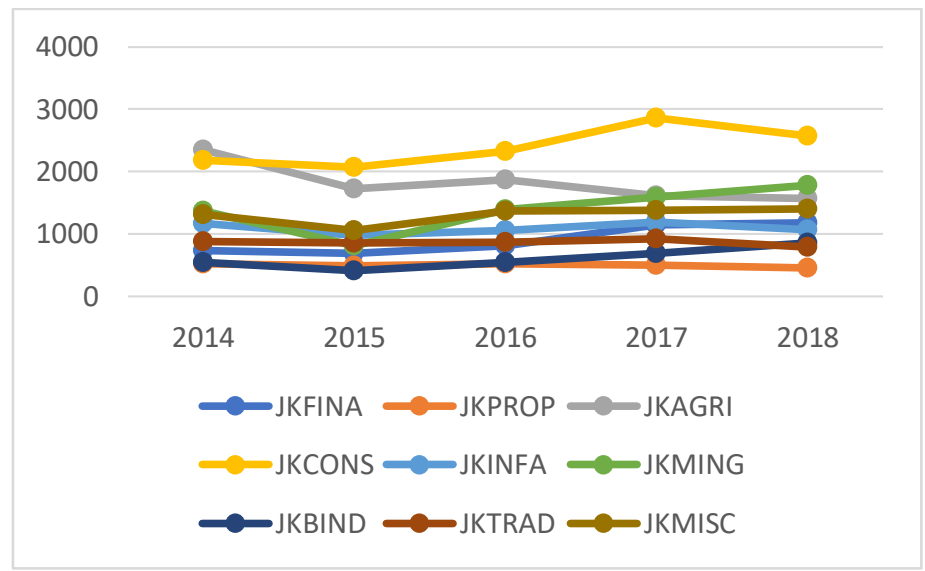

Sumber: idx.co.id (2020, diolah)

\section{Gambar 1. PERGERAKAN INDEK HARGA SAHAM DI BEI PERIODE 2014-2018}

Pada gambar 1, dapat dilihat Negara Indonesia saat ini memiliki sembilan sektor yang terdaftar di Bursa Efek Indonesia (BEI). Rata-rata sektor menurun sampai pada tahun 2014 hingga tahun 2015. Penurunan pada sektor finance, property, trad, dan sektor industri menghadapi penurunan yang kecil dibanding sektor lain. Pada 2015, rata-rata sektor meningkat sampai tahun 2016. Kenaikan yang paling besar dialami oleh sektor pertambangan yaitu sebesar 58,5\%. Pada 2016, hanya pada sektor property dan agribisnis yang mengalami penurunan sampai pada tahun 2017. Sektor cons goods mengalami kenaikan yang paling tinggi daripada sektor lainnya, yaitu sebesar 23,10\%. Pada 2017, sektor property, agriculture, cons good, infrastruktur, dan trad menurun sampai dengan tahun 2018, sedangkan sektor lain meningkat. Pada gambar 1, terlihat setiap sektor memiliki volatilitas berbedabeda. Di BEI terdapat 9 sektor yang terdaftar, namun terdapat satu sektor yang mempunyai tingkat fluktuatif yang tinggi yaitu sektor finance.

Berdasarkan penelitian terdahulu, terdapat beberapa hal yang memiliki efek terhadap volatilitas harga saham. Faktor pertama yaitu dividend payout ratio. Pada hakikatnya, dividend payout ratio (DPR) menjelaskan rasio laba bersih yang didapatkan oleh perusahaan yang dialokasikan untuk pembagian dividen kepada investor atau ditahan guna mendanai kegiatan operasional perusahaan yang disebut dengan laba ditahan (Kautsar, 2019). Jannah \& Haridhi (2016) \& Surahmat et al. (2017) menemukan hasil bahwa volatilitas harga saham mempunyai pengaruh negatif secara signifikan terhadap dividend payout ratio. Pendapat yang berbeda dinyatakan oleh Andiani \& Gayatri (2018) \& Rohmawati (2017) 
mengemukakan bahwa volatilitas harga saham berpengaruh positif secara signifikan terhadap dividend payout ratio. Di sisi lain, Rowena \& Hendra (2017) \& Theresia \& Arilyn (2015) memberi pernyataan bahwa dividend payout ratio berpengaruh negatif terhadap volatilitas harga saham.

Dividend yield merupakan hal yang juga dijadikan fokus perhatian para investor dalam pelaksanaan kegiatan investasinya (Andiani \& Gayatri, 2018). Berbeda dengan dividend payout ratio yang berhubungan secara pendapatan dan juga dividen yang diberikan, dividend yield lebih bergantung terhadap harga pasar saat ini (Jannah \& Haridhi, 2016). Ahmad et al., (2018) memberi penjelasan bahwa dividend yield berpengaruh negatif secara signifikan dengan volatilitas harga saham. Pendapat yang berbeda dinyatakan oleh Dewi \& Paramita (2019) \& Surahmat et al., (2017) memberi penjelasan bahwa dividend yield berpengaruh positif secara signifikan dengan volatilitas harga saham. Di sisi lain, Dominika \& Yanti, (2019) \& Theresia \& Arilyn (2015) menyatakan bahwa dividend yield berpengaruh negatif dengan volatilitas harga saham.

Leverage adalah rasio untuk mengetahui seberapa besar kebergantungan perusahaan terhadap utang (Fahmi, 2012). Jannah \& Haridhi (2016) menyatakan bahwa volatilitas harga saham memiliki pengaruh signifikan positif terhadap leverage. Pendapat berbeda dinyatakan Priana \& Muliartha (2017), yang mengemukakan hasil sebaliknya yaitu volatilitas harga saham memiliki pengaruh signifikan negatif terhadap leverage. Di sisi lain, Dominika \& Yanti (2019), \& Ilmiyono (2017) menyatakan bahwa volatilitas harga saham tidak memiliki pengaruh sama sekali terhadap leverage.

Peningkatan dan penurunan harga suatu saham juga dipengaruhi oleh earning volatility. Earning volatility menggambarkan tingkat volatilitas laba yang diperoleh perusahaan (Jannah \& Haridhi, 2016). Perusahan dikatakan baik jika memiliki pendapatan laba yang stabil. Jannah \& Haridhi (2016) dalam penelitiannya menemukan hasil bahwa volatilitas harga saham mempunyai pengaruh signifikan positif terhadap earning volatility. Pendapat berbeda dinyatakan oleh Rowena \& Hendra (2017) \& Surahmat et al., (2017) menyatakan bahwa earning volatility berpengaruh signifikan negatif terhadap volatilitas harga saham. Di sisi lain, Dominika \& Yanti (2019) \& Theresia \& Arilyn (2015) menyatakan bahwa volatilitas harga saham tidak mempunyai pengaruh terhadap earning volatility.

Volume pedagangan saham menggambarkan reaksi pasar terhadap respon yang diberikan oleh investor (Priana \& Muliartha, 2017). Volume perdagangan saham merupakan hal yang penting bagi investor karena dapat memengaruhi harga saham perusahaan, karena volume perdagangan menggambarkan kondisi efek yang diperjual belikan di pasar modal yang mempunyai dampak pada harga saham (Rahayu \& Masud, 2019). Dewi \& Suaryana (2016) \& Rohmawati (2017) dalam penelitiannya menemukan hasil bahwa volatilitas harga saham mempunyai pengaruh signifikan positif terhadap volume perdagangan. Pendapat lain dinyatakan oleh Priana \& Muliartha (2017), menyatakan bahwa volatilitas harga saham mempunyai pengaruh signifikan negatif terhadap volume perdagangan. Di sisi lain, Andiani \& Gayatri (2018) \& Dewi \& Paramita (2019) menyatakan bahwa volume perdagangan tidak mempunyai pengaruh dengan volatilitas harga saham.

Tujuan penelitian ini adalah memahami bagaimana pengaruh kebijakan dividen, leverage, earning volatility, dan volume perdagangan terhadap volatilitas harga saham pada perusahaan sektor finance.

\section{KAJIAN PUSTAKA DAN PENGEMBANGAN HIPOTESIS}

\section{Teori The Bird Hand}

Dalam investasi, bird in the hand theory ini merupakan perumpamaan satu burung dalam genggaman lebih bernilai daripada seribu burung yang terbang di udara. Perumpamaan tersebut digambarkan untuk menggambarkan bahwa dividen yang didapatkan oleh pemegang saham saat ini lebih bernilai dibandingkan keuntungan lain yang diterima dalam di masa mendatang seperti capitan gain (Mulyaningsih \& Rahayu, 2016). 
Ayuda Rizkya Utami \& Purwohandoko. Pengaruh Kebijakan Dividen, Leverage, Earning Volatility, dan Volume Perdagangan terhadap Volatilitas Harga Saham pada Perusahaan Sektor Finance yang Terdaftar di BEI Tahun 2014-2018

\section{Teori Sinyal (Signalling Theory)}

Signaling Theory yang dikembangkan oleh Ross (1977), mengemukakan bahwa informasi yang berkaitan dengan kondisi suatu perusahaan dimiliki dengan baik oleh pihak eksekutif dalam perusahaan, selanjutnya informasi tersebut akan disampaikan kepada calon investor. Jannah \& Haridhi (2016) menyatakan bahwa teori sinyal (signaling theory) merupakan cara suatu perusahaan dalam menyampaikan sebuah sinyal terhadap investor. Sinyal yang disampaikan berupa informasiinformasi berhubungan dengan kinerja perusahaan yang dibutuhkan oleh investor, khususnya apabila informasi tersebut berita yang positif. Jika informasi yang diberikan oleh perusahaan bersifat baik, maka pasar yang telah menerima informasi tersebut diharapkan merespon dengan baik pula (Nuswandari, 2009).

\section{Volatilitas Harga Saham}

Volatilitas harga saham yaitu memahami harga suatu saham yang mengalami aktivitas naik turun. Volatilitas harga saham yaitu tolak ukur untuk menentukan sebesar apakah risiko dari suatu saham (Ullah et al., 2015). Volatilitas harga saham dapat dialami oleh perusahaan apabila harga saham tersebut berfluktuatif. Saham dapat dikatakan volatile apabila perubahannya cukup besar dan signifikan (Theresia \& Arilyn, 2015). Rumus perhitungan PVOL sesuai dengan Jannah \& Haridhi (2016), Rowena \& Hendra (2017), Dewi \& Paramita (2019) dapat dilihat di rumus (1).

PVOL $=\sqrt{\left.\sum \frac{\left\{\frac{\left(\mathrm{H}_{i}-\mathrm{Li}\right)}{\left(\frac{\mathrm{Hi}+\mathrm{Li}}{2}\right)}\right.}{12}\right\}^{2}}$

Keterangan:

$P V O L$ : Volatilitas Harga Saham

$H_{i} \quad$ : Harga saham penutupan tertinggi dalam satu tahun $i$

$L_{\mathrm{i}} \quad$ : Harga saham penutupan terendah dalam satu tahun $i$

Nilai $I$ : nilai dari 1 sampai $\mathrm{n}$

\section{Kebijakan Dividen}

Rowena \& Hendra (2017) kebijakan dividen merupakan perusahaan yang telah mendapatkan keuntungan mempunyai ketentuan apakah nantinya diberikan kepada investor menjadi laba yang ditahan atau dalam bentuk dividen, yang akan digunakan sebagai pembiayaan investasi di masa mendatang. Pembayaran dividen menjadi suatu persoalan yang menarik dalam literatur keuangan (Kautsar, 2014). Kebijakan dividen diproksikan menggunakan dividend payout ratio (DPR) dan dividend yield (DY).

Dividend payout ratio menggambarkan seberapa besar perusahaan menggunakan laba bersihnya untuk melakukan pembayaran kepada investor menggunakan dividen. Perhitungan dividend payout ratio sesuai dengan penelitian Ardiansyah \& Isbanah (2017) dapat dilihat di rumus (2).

$\mathrm{DPR}=\frac{\text { Dividend Per Share }}{\text { Earning per share }}$

Dividend yield dapat diketahui dengan melihat harga saham saat ini sehingga dapat diketahui seberapa besar suatu perusahaan memberikan dividen kepada investor (Azura et al., 2018). Perhitungan dividend yield sesuai dengan penelitian Dewi \& Paramita (2019) dapat dilihat di rumus (3).

$\mathrm{DY}=\frac{\text { Dividend Per Share }}{\text { Price Share }}$ 


\section{Leverage}

Rasio leverage digunakan dalam menghitung seberapa besar penggunaan utang yang dipakai untuk melakukan kegiatan dalam perusahaan (Fahmi, 2012). Leverage merupakan tingkat kemampuan perusahaan dalam menggunakan aktiva atau hutang dalam mewujudkan tujuan perusahaan (Purwohandoko et al., 2014). Selpiana \& Badjra (2018) mengatakan bahwa perbandingan rasio yang menunjukkan total modal sendiri dengan total utang disebut sebagai debt to equity ratio. Rasio DER meggambarkan kesanggupan perusahaan dalam memenuhi kewajibannya yang ditunjukkan oleh sebagian modal sendiri yang digunakan untuk membayar hutang perusahaan (Kautsar, 2014). Rasio yang digunakan sesuai dengan penelitian Selpiana \& Badjra (2018) dan Sova (2013) diformulasikan dengan rumus (4).

$\mathrm{DER}=\frac{\text { Total Debt }}{\text { Toal Equity }}$

\section{Earning Volatility}

Earning volatility (volatilitas laba) merupakan cerminan dari peningkatan dan penurunan laba yang diperoleh perusahaan pada waktu tertentu (Rowena \& Hendra, 2017). Earning volatility merupakan parameter yang digunakan untuk mengetahui tingkat konsisten laba yang didapatkan oleh perusahaan setiap tahunnya. Volatilitas laba dilambangkan dengan Evol, pengukurannya dengan standar deviasi EBIT dengan total asset (Jannah \& Haridhi, 2016). Dalam penelitian ini pengukuran earning volatility sesuai dengan penelitian Dewi \& Paramita (2019) dan Jannah \& Haridhi (2016) diformulasikan dengan rumus (5).

$\mathrm{EVOL}=\mathrm{STD} \frac{\text { EBIT }}{\text { Total Asset }}$

Keterangan:

EVOL : Earning Volatility

STD : Standar Defiasi

EBIT : Earning Before Interest and Tax.

\section{Volume Perdagangan}

Volume perdagangan saham dapat dijadikan indikator dalam melihat kondisi suatu bursa, semakin besar volume perdagangan maka semakin banyak investor yang tertarik pada saham tersebut artinya semakin banyak pula lembar saham yang ditransaksikan (Khajar, 2016). Perubahan volume perdagangan saham memperlihatkan aktivitas saham di bursa sehingga dapat membuat para investor untuk memutuskan berinvestasi. Dalam penelitian ini perhitungan volume perdagangan sesuai dengan penelitian Dewi \& Paramita (2019), Rohmawati (2017), dan Azura et al., (2018) dapat dilihat di rumus (6).

$\mathrm{VP}=$ Ln Tradeable Shares

\section{Hubungan Antar Variabel}

Dividend payout ratio yang memiliki nilai tinggi memberikan sinyal positif terhadap investor, sehingga keinginan investor untuk menanamkan sahamnya di perusahaan semakin besar. Hal ini dikarenakan bertambahnya kapabilitas perusahaan dalam memperoleh keuntungan yang diimbangi dengan semakin banyaknya laba yang diberikan kepada investor, sehingga permintaan saham itu semakin besar dan harga saham mengalami peningkatan (Ardiansyah \& Isbanah, 2017). Teori The Bird Hand sangat sesuai dengan hal tersebut karena berpendapat bahwa investor lebih memilih untuk mendapatkan penghasilan berupa dividen daripada mengharapkan capital gain (Mulyaningsih \& Rahayu, 2016).

H1: Dividend payout ratio mempunyai pengaruh terhadap volatilitas harga saham pada perusahaan sektor finance. 
Ayuda Rizkya Utami \& Purwohandoko. Pengaruh Kebijakan Dividen, Leverage, Earning Volatility, dan Volume Perdagangan terhadap Volatilitas Harga Saham pada Perusahaan Sektor Finance yang Terdaftar di BEI Tahun 2014-2018

Dividend yield berhubungan dengan dividen dan laba per lembar saham yang telah dibagikan, dividend yield sangat bergantung dengan harga pasar (Jannah \& Haridhi, 2016). Apabila perusahaan memiliki kemampuan yang besar dalam memberikan dividen, maka perusahaan akan menghasilkan keuntungan yang tinggi. Dengan bertambahnya kemampuan perusahaan dalam membagikan dividen, sehingga investor cenderung menahan sahamnya (Dewi \& Paramita, 2019). Hal ini menyebabkan harga saham naik dan volatilitas harga saham menurun.

H2: Dividend yield mempunyai pengaruh terhadap volatilitas harga saham pada perusahaan sektor finance.

Angka DER yang semakin tinggi dapat diperkirakan bahwa perusahaan mempunyai risiko yang besar terhadap tingkat likuiditas perusahaannya, hal tersebut membuat volatilitas harga saham akan ikut meningkat (Jannah \& Haridhi, 2016). Hal tersebut membuat investor mendapat sinyal yang negatif. Perusahaan yang memiliki DER tinggi membuat investor tidak memilih menanamkan sahamnya di perusahaan tersebut (Kurniasih \& Surachim, 2018). Hal ini menyababkan harga saham menjadi turun dan volatilitas harga saham meningkat.

H3: Leverage memiliki pengaruh terhadap volatilitas harga saham pada perusahaan sektor finance.

Earning volatility merupakan cerminan dari peningkatan dan penurunan keuntungan yang diperoleh perusahaan pada waktu tertentu (Rowena \& Hendra, 2017). Earning volatility yang tinggi menjelaskan bahwa perusahaan belum optimal dalam menjaga kestabilan labanya. Hal ini menyababkan risiko bisnis yang dialami oleh perusahaan meningkat, sehingga memberikan sinyal negatif bagi investor (Mobarak \& Mahfud, 2017). Informasi tersebut menyebabkan investor menghindari saham perusahaan yang mempunyai earning volatility yang tinggi. Hal ini menyebabkan harga saham semakin turun, dan volatilitas harga saham meningkat.

H4: Earning volatility memiliki pengaruh terhadap volatilitas harga saham pada perusahaan sektor finance.

Volume perdagangan menunjukkan tingkat transaksi jual beli yang terjadi di bursa. Semakin tinggi nilai volume perdagangan diartikan bahwa banyaknya lembar saham yang diperjualbelikan semakin meningkat (Khajar, 2016). Hal tersebut membuktikan bahwa saham perusahaan sedang mengalami performa baik, yang menyebabkan investor tertarik untuk menanamkan sahamnya (Kristanto \& Idris, 2016). Hal ini menyebabkan investor memilih untuk menaham sahamnya diperusahaan dan harga saham akan meningkat. Hal ini menyababkan volatilitas harga saham menurun.

H5: Volume perdagangan berpengaruh dengan volatilitas harga saham pada perusahaan sektor finance.

\section{METODE PENELITIAN}

Penelitian ini merupakan penelitian kausalitas, tujuannya adalah menelhihiiti hubungan sebab akibat antara variabel bebas antara lain kebijakan dividen, leverage, earning volatility, dan volume perdagangan dengan variabel terikat yaitu volatilitas harga saham. Data yang dipakai dalam penelitian ini berasal dari laporan keungan perusahaan dan menggunakan data kuantitatif, yang diakses melalui Indonesia Stock Exchange (www.idx.co.id). Dalam penelitian ini populasi yang dipakai ialah perusahaan sektor finance pada tahun 2014-2018 terdaftar di Bursa Efek Indonesia. Metode pengumpulan sampel menggunakan purposive sampling, kriteria yang digunakan dalam menentukan sampel, yaitu perusahaan sektor finance yang memiliki kelengkapan data variabel yang dibutuhkan dan menerbitkan laporan keuangan selama tahun 2014-2018, perusahaan sektor finance yang membayarkan dividen kepada pemegang saham sebanyak 3 kali atau lebih selama tahun 2014-2018, perusahaan sektor finance yang tidak pernah melakukan corporate issue (stock split, reverse stock dan 
right issue) selama periode penelitian. Analisis regresi linier berganda merupakan metode yang digunakan untuk menguji penelitian ini, dan menggunakan alat analisis software SPSS versi 25.

\section{HASIL DAN PEMBAHASAN}

\section{Hasil Uji Normalitas}

One-Sample Kolmogorov smirnov (K-S) digunakan untuk pengujian normalitas dan dikatakan normal saat nilai signifikan di atas 0,05, dengan demikian dapat diasumsikan data penelitian tersebut berdistribusi normal. Dari uji K-S ini memiliki hasil nilai signifikansi sejumlah 0,116. Angka probabilitas menghasilkan nilai 0,05 yang berarti lebih besar, sehingga penelitian ini telah berdistribusi normal.

\section{Hasil Uji Multikolonieritas}

Untuk mengetahui adanya korelasi antar variabel independen, maka dilakukan uji multikolonieritas. Melihat apakah gejala multikolonieritas ada dalam model regresi yang terlihat pada nilai tolerance $\leq$ 10 dan nilai VIF nya $\geq 10$, menunjukkan adanya gejala multikolonieritas. Hasil uji multkolonieritas menunjukkan bahwa nilai tolerance > 0,10 masing-masing dimiliki oleh variable independen dan nilai varianvce inflation factor $(\mathrm{VIF})<10$. Sehingga dari hasil uji tersebut bisa disimpulkan bahwa multikolonieritas tidak terdapat dalam model regresi dan data layak untuk diuji lebih lanjut.

\section{Hasil Uji Autokorelasi}

Uji Durbin-Watson dipakai untuk mengidentifikasi gejala autokorelasi dalam penelitian ini. Data dikatakan bebas dari autokerelasi apabila nilai Durbin-Watson (DW Test) memenuhi persamaan du $<\mathrm{dw}<4-\mathrm{du}$. Berdasarkan hasil menunjukkan nilai Durbin-Watson sebesar 1,875. Selanjutnya, mencari nilai du dengan melihat table DW dengan signifikansi sebesar 5\% dengan rumus $(\mathrm{k} ; \mathrm{n})$, diketahui $\mathrm{k}$ merupakan jumlah variabel independen dan $\mathrm{n}$ adalah jumlah data sampel yang diobservasi. Pada penelitian ini, $\mathrm{k}=5$ dan $\mathrm{n}=85$. Dengan demikian diperoleh nilai du sebesar 1,7736 , setelah mendapatkan nilai du kemudian dimasukkan kedalam persamaan $\mathrm{du}<\mathrm{dw}<4$-du, maka 1,7736 < $1.875<2.125$ yang berarti dalam model regresi ini tidak terjadi autokorelasi.

\section{Hasil Uji Heteroskedastisitas}

Salah satu metode dalam memprediksi heteroskedasitisitas adalah menggunakan diagram scatterplot. Penyebaran titik-titik pada grafik scatterplot menyebar di daerah atas dan bawah angka 0 pada sumbu Y. Uji heteroskedastisitas juga dilakukan menggunakan uji glejser, dengan hasil yang memperlihatkan bahwa variabel DPR, DY, leverage, earning volatility, dan volume perdagangan memiliki nilai signifikan $0,112,0,499,0,187,0,228,0,591$ yang artinya dalam penelitian ini memiliki nilai signifikan > 0,05 hal ini sesuai dengan dasar pengambilan keputusan metode glejser. Maka dapat diartikan bahwa model regresi ini tidak mengandung adanya heteroskedastisitas.

\section{Hasil Uji Linieritas}

Pengujian linieritas dalam penelitian ini dilihat melalui uji Lagrange Multiplier, dengan hasil terdapat nilai $\mathrm{R}^{2}$ sebesar 0,254 dengan jumlah variabel $(\mathrm{N}) 85$, maka hasil $\mathrm{c}^{2}$ hitung yaitu $\mathrm{N} X R$ square $(85 \mathrm{x}$ $0,254)=21,59$. Sementara itu, diketahui bahwa nilai $\mathrm{df}=84$ dan dengan tingkat signifikansi sebesar 0,05 , sehingga diperoleh nilai $\mathrm{c}^{2}$ tabel sebesar 106,394. Dengan begitu maka diperoleh nilai 21,59 < 106,394 yaitu berarti nilai $c^{2}{ }_{\text {hitung }}$ lebih kecil dari $\mathrm{c}^{2}{ }_{\text {tabel}}$, sehingga dapat diartikan bahwa model regresi lolos uji linieritas.

\section{Hasil Uji Statistik F (Uji Kelayakan Model)}

Uji statistic dalam penelitian ini menggunakan tingkat kepercayaan 95\% dan tingkat kemiripan atau batas ketidakakuratan sebesar $\alpha=5 \%$. Hasil uji f dalam penelitian ini ditunjukkan pada tabel 1 .

Berdasarkan tabel 1, dapat diketahui bahwa nilai signifikansi sebesar 0,000 lebih kecil dari 0,05, sedangkan nilai $F_{\text {hitung }}$ sebesar 2,33. Dengan demikian, diketahui bahwa nilai $F_{\text {hitung }}>F_{\text {tabel }}$ $(5,392>2,33)$, sehingga $\mathrm{H}_{0}$ ditolak dan Ha diterima. Sehingga diartikan bahwa dividend payout ratio, 
Ayuda Rizkya Utami \& Purwohandoko. Pengaruh Kebijakan Dividen, Leverage, Earning Volatility, dan Volume Perdagangan terhadap Volatilitas Harga Saham pada Perusahaan Sektor Finance yang Terdaftar di BEI Tahun 2014-2018

dividend yield, leverage, earning volatility, dan volume perdagangan berpengaruh terhadap volatilitas harga saham.

Tabel 1.

HASIL UJI STATISTIK F

\begin{tabular}{llccccc}
\hline \multicolumn{1}{l}{ Model } & Sum of Squares & Df & $\begin{array}{c}\text { Mean } \\
\text { Square }\end{array}$ & F & Sig. \\
\hline \multirow{3}{*}{1} & Regression & .177 & 5 & .035 & 5.392 & $.000^{\mathrm{b}}$ \\
Residual & .519 & 79 & .007 & & \\
\cline { 2 - 5 } & Total & .696 & 84 & & & \\
\hline
\end{tabular}

Sumber: Output SPSS (2020, data diolah)

\section{Hasil Uji Statistik t (Uji Signifikansi Individual)}

Dalam penelitian ini, signifikansi yang dipakai dalam uji ini jika nilai $\alpha \leq 0,05$ maka variabel independen secara parsial berpengaruh signifikan terhadap variabel independen.

Tabel 2.

\section{HASIL UJI STATISTIK T}

\begin{tabular}{llccccc}
\hline & & \multicolumn{2}{c}{$\begin{array}{c}\text { Unstandardized } \\
\text { Coefficients }\end{array}$} & $\begin{array}{c}\text { Standardized } \\
\text { Coefficients }\end{array}$ & & \\
& Model & B & Std. Error & Beta & T & Sig. \\
\hline 1 & (Constant) & .155 & .030 & & 5.211 & .000 \\
& DPR (X1) & .103 & .041 & .300 & 2.517 & .014 \\
& DY(X2) & .357 & & .256 & 2.176 & .033 \\
& & .164 & & & \\
& DER (X3) & -.003 & .004 & -.095 & -.787 & .434 \\
& EVOL (X4) & -.145 & .134 & -.108 & -1.081 & .283 \\
& VP (X5) & -.001 & .002 & -.044 & -.365 & .716 \\
\hline
\end{tabular}

Sumber: Output SPSS (2020, data diolah)

Berdasarkan tabel 2. Uji statistic t memperlihatkan hasil sebagai berikut. Nilai signifikansi yang dimiliki dividend payout ratio (DPR) sebesar 0,014 yang artinya nilai yang dimiliki lebih kecil dari $0,5(0,014<0,05)$, maka $\mathrm{H}_{0}$ tidak diterima dan $\mathrm{H}_{\mathrm{a}}$ diterima. Dari hal tersebut dapat dikatakan bahwa volatilitas harga saham mempunyai pengaruh yang signifikan terhadap DPR. Lalu nilai signifikansi yang dimiliki dividend yield (DY) memiliki nilai sebesar 0,033 yang artinya lebih kecil dari 0,5 $(0,033$ $<0,05)$ menunjukkan bahwa $\mathrm{H}_{0}$ tidak diterima dan Ha diterima. Dari hal tersebut volatilitas harga saham mempunyai pengaruh signifikan terhadap dividend yield. Leverage memiliki nilai signifikansi sebesar 0,434 yang berarti lebih besar dari 0,5 $(0,434>0,05)$ menunjukkan bahwa $\mathrm{H}_{0}$ diterima dan $\mathrm{Ha}$ ditolak yang artinya adalah leverage tidak berpengaruh signifikan terhadap volatilitas harga saham. Earning Volatility memiliki nilai signifikansi sebesar 0,238 yang berarti lebih besar dari 0,5 $(0,238>$ $0,05)$ menunjukkan bahwa $\mathrm{H}_{0}$ diterima dan $\mathrm{Ha}$ ditolak yang artinya adalah earning volatility tidak berpengaruh signifikan terhadap volatilitas harga saham. Volume perdagangan memiliki nilai signifikansi sebesar 0,716 yang berarti lebih besar dari $0,5(0,716>0,05)$ menunjukkan bahwa Ho diterima dan Ha ditolak yang artinya adalah volume perdagangan tidak berpengaruh signifikan terhadap volatilitas harga saham.

\section{Hasil Analisis Regresi Berganda}

Persamaan regresi didapat dari hasil analisis regresi linier berganda pada tabel 2. Berdasarkan tabel 2, persamaan regresi linier berganda dapat dilihat pada rumus (7).

$\mathrm{Y}=0,155+0,103 \mathrm{DPR}+0,357 \mathrm{DY}+\mathrm{e}$ 
Hasil dari persamaan tersebut menunjukkan bahwa, jika nilai konstanta $(\alpha)$ sebesar 0,155 bermakna apabila nilai dividend yield, dividend payout ratio, earning volatility dan volume perdagangan bernilai sama dengan nol (0) atau konstan, maka nilai volatilitas harga saham sebesar 0,155 . Koefisien regresi dividend payout ratio ( $\beta 1$ ) sebesar 0,103 dengan asumsi nilai variabel independen lainnya tetap, berarti apabila terjadi perubahan dividend payout ratio, maka nilai volatilitasnya akan mengalami peningkatan sebesar 0,103. Koefisien regresi dividend yield ( $\beta 2)$ sebesar 0,357 dengan asumsi nilai variabel lainnya tetap, maka apabila ada perubahan satu satuan dividend yield, nilai volatilitas harga saham akan meningkat sebesar 0,357. e adalah error yang berarti bahwa ada variabel independen di luar variabel penelitian yang dapat memengaruhi variabel independen.

\section{Hasil Uji Koefisien Determinasi (Adjusted $\boldsymbol{R}^{2}$ )}

Hasil uji koefisien determinasi menunjukkan nilai Adjusted $\mathrm{R}^{2}$ sejumlah 0,207, hal ini bermakna bahwa $20,7 \%$ variasi volatilitas harga saham dijelaskan oleh variasi dari dividend payout ratio, dividend yield, leverage, earning volatility, dan volume perdagangan. Sementara itu, sisanya sejumlah $79,3 \%$ dapat memengaruhi volatilitas harga saham dan dijelaskan oleh variabel lain di luar penelitian ini.

\section{Pengaruh Dividend Payout Ratio Terhadap Volatilitas Harga Saham}

Berdasarkan data analisis statistik yang menghasilkan nilai signifikan dan menjelaskan bahwa dividend payout ratio mempunyai pengaruh yang positif terhadap volatilitas harga saham. Penelitian Ardiansyah \& Isbanah (2017) \& Rohmawati (2017) memiliki hasil yang sesuai dengan penelitian ini. Teori The Bird Hand investor juga sesuai yang berharap dividen yang dibagikan ini mempunyai resiko yang rendah dan dipercayai oleh investor ketimbang mendapat capital gain di masa yang akan datang (Mulyaningsih \& Rahayu, 2016). Dengan adanya pembayaran dividen berarti kemampuan perusahaan dalam memperoleh laba juga meningkat, maka berpengaruh dengan meningkatnya harga saham. Hal tersebut disebabkan oleh perusahaan yang mempunyai kapasitas dalam menghasilkan saham dengan laba yang tinggi membuat para investor tergiur untuk memilikinya, sehingga saham tersebut akan tinggi permintaannya dan meningkatkan volatilitas harga saham.

Berdasarkan data perusahaan BJBR pada tahun 2016 mengalami peningkatan nilai dividend payout ratio dan di waktu yang sama volatilitas harga saham perusahaan BJBR juga meningkat. Selain itu, perubahan dividend payout ratio terhadap volatilitas harga saham yang searah juga dialami oleh perusahaan BBNI. Hal tersebut dibuktikan dengan adanya kenaikan dividend payout ratio yang diiringi dengan meningkatnya volatilitas harga saham dengan tahun sebelumnya selama periode penelitian. Dapat disimpulkan bahwa perusahaan yang memiliki nilai dividend payout ratio yang tinggi akan memiliki tingkat volatilitas harga saham yang tinggi.

Penelitian ini mendukung teori The bird hand yang menekankan bahwa investor lebih cenderung memilih untuk memperoleh pendapatan berupa pembayaran dividen daripada capital gain (Mulyaningsih \& Rahayu, 2016). Dengan tingginya nilai dividend payout ratio membuat para investor tertarik untuk memiliki saham perusahaan sehingga permintaan saham akan mengalami peningkatan dan menyebabkan saham tersebut mengalami volatilitas harga saham yang tinggi. Implikasi praktis dari penelitian yaitu, perusahaan harus memperhatikan besaran nilai dividend yang dibagikan serta pengelolaan asset perusahaan agar dapat meminimalisir volatilitas harga saham, dengan pembagian dividen yang besar dan pngelolaan asset perusahaan yang baik akan membuat investor tertarik untuk berinvestasi di perusahaan.

\section{Pengaruh Dividend Yield terhadap Volatilitas Harga Saham}

Berdasarkan data analisis statistik yang menghasilkan nilai signifikan dan menjelaskan bahwa dividend yield mempunyai pengaruh yang positif terhadap volatilitas harga saham. Penelitian Ardiansyah \& Isbanah, (2017) \& Rohmawati (2017) sejalan dengan hasil penelitian ini yaitu dikarenakan dividend yield merupakan perbandingan antara DPS dengan harga saham. Artinya, jika nilai dividend yield meningkat berarti harga saham perusahaan sedang menurun, sehingga dikatakan 
Ayuda Rizkya Utami \& Purwohandoko. Pengaruh Kebijakan Dividen, Leverage, Earning Volatility, dan Volume Perdagangan terhadap Volatilitas Harga Saham pada Perusahaan Sektor Finance yang Terdaftar di BEI Tahun 2014-2018

tingkat risiko yang tinggi dimiliki oleh perusahaan sehingga untuk mendapat capital gain akan sulit, dan harga saham akan menjadi lebih berfluktuatif.

Berdasarkan data perusahaan ASRM pada tahun 2016 mengalami peningkatan dividend yield dan di waktu yang bersamaan volatilitas harga saham perusahaan ASRM juga meningkat. Selain itu, perubahan dividend yield dan volatilitas harga saham yang searah juga dialami oleh perusahaan LPGI. Hal tersebut dibuktikan dengan adanya kenaikan dividend yield yang diiringi dengan meningkatnya volatilitas harga saham dengan tahun sebelumnya selama periode penelitian. Dapat disimpulkan bahwa perusahaan yang memiliki nilai dividend yield yang tinggi akan memiliki tingkat volatilitas harga saham yang tinggi.

Penelitian ini bertentangan dengan teory the bird hand yang mengatakan bahwa besarnya nilai dividend yield akan menyebabkan nilai volatilitas harga saham yang rendah (Mulyaningsih \& Rahayu, 2016). Hal ini dikarenakan, jika nilai dividend yield meningkat maka investor cenderung untuk menahan sahamnya, dan menyebabkan volatilitas harga sahamnya menurun. Implikasi praktis dari penelitian yaitu, perusahaan harus memperhatikan besaran nilai dividend yang dibagikan serta pengelolaan asset perusahaan agar dapat meminimalisir volatilitas harga saham, dengan pembagian dividen yang besar dan pngelolaan asset perusahaan yang baik akan membuat investor tertarik untuk berinvestasi di perusahaan.

\section{Pengaruh Leverage terhadap Volatilitas Harga Saham}

Berdasarkan hasil pengujian dengan menggunakan regresi linear berganda leverage tidak mempunyai pengaruh dengan volatilitas harga saham perusahaan finance yang terdaftar di Bursa Efek Indonesia tahun 2014-2018. Artinya, setiap perubahan nilai leverage tidak mempunyai pengaruh dengan tingkat volatilitas harga saham. Ardiansyah \& Isbanah (2017) \& Ilmiyono, (2017) menghasilkan penelitian yang sama dengan penelitian ini bahwa hal tersebut dikarenakan oleh sampel data yang diteliti merupakan perusahaan sektor keuangan. Di mana perusahaan dalam penelitian ini beroperasi di aspek keuangan seperti, perusahaan investasi, asuransi, dll. Perusahaan ini lebih cenderung mempunyai nilai yang tinggi dalam DER. Hal tersebut dikarenakan dana berasal dari pihak ketiga yang sebagian besar dikelola dalam perusahaan ini. Di mana dalam akuntansi, dana pihak ketiga ditafsirkan sebagai hutang. Selain itu, dalam mengukur kinerja pasar, investor tidak selalu melihat DER untuk memprediksi harga saham (Dewi \& Suaryana, 2016).

Data penelitian menunjukkan bahwa perubahan dari naik turunnya DER belum tentu memengaruhi volatilitas harga saham perusahaan. Penelitian ini bertentangan dengan signaling theory yang menyatakan bahwa informasi mengenai tinggi rendahnya debt to equity ratio berpengaruh terhadap volatilitas harga saham. Tingginya nilai DER berarti perusahaan cenderung ketergantungan terhadap hutang pihak eksternal dalam membiayai kegiatan operasionalnya. Hal tersebut yang menyebabkan saham perusahaan dengan nilai DER tinggi dihindari oleh para investor karena dianggap memiliki risiko yang tinggi. Implikasi praktis dari penelitian yaitu, perusahaan finance tidak harus memperhatikan nilai leverage dalam mengendalikan nilai volatilitas harga saham. Perusahaan sebaiknya mempertimbangkan hal lain yang mampu memengaruhi volatilitas harga saham sehingga, perusahaan dapat meminimalisir tingkat volatilitas harga saham.

\section{Pengaruh Earning Volatility terhadap Volatilitas Harga Saham}

Berdasarkan pengujian dengan menggunakan regresi linear berganda earning volatility tidak mempunyai pengaruh dengan volatilitas harga saham perusahaan finance yang terdaftar di Bursa Efek Indonesia tahun 2014-2018. Artinya, setiap perubahan nilai earning volatility tidak mempunyai pengaruh dengan tingkat volatilitas harga saham. Dewi \& Paramita (2019) \& Theresia \& Arilyn (2015) menghasilkan penelitian yang sama dengan penelitian ini. Hal tersebut disebabkan oleh investor suatu perusahaan memberikan faktor kepercayaan yang besar. Meskipun perusahaan menghasilkan laba yang tidak stabil, akan tetapi dividen masih dapat dan mampu dibagikan oleh perusahaan, maka investasi di dalam perusahaan tersebut tetap dilakukan oleh para investor karena 
masih tertarik dengan perusahaan tersebut. Investor cenderung berkonsentrasi terhadap pengembalian dividen, sehingga earning volatility tidak terlalu memengaruhi keputusan investasi dari investor.

Berdasarkan data perusahaan MEGA, pada saat earning volatility mengalami kenaikan maupun penurunan, volatilitas harga saham tidak mengalami perubahan yang searah dengan nilai earning volatility. Data tersebut menunjukkan bahwa perubahan nilai earning volatility belum tentu berpengaruh terhadap volatilitas harga saham.

Penelitian ini bertentangan dengan signaling theory yang menyatakan bahwa informasi mengenai earning volatility dapat berpengaruh terhadap volatilitas harga saham. Tingginya nilai earning volatility diartikan bahwa perusahaan belum mampu menjaga kestabilan nilai pendapatan perusahaan. Tingginya nilai earning volatility menyebabkan risiko investasi menjadi lebih tinggi dan harga saham bergerak fluktuatif. Implikasi praktis dari penelitian yaitu, perusahaan finance tidak harus memperhatikan nilai earning volatility dalam mengendalikan nilai volatilitas harga saham. Perusahaan sebaiknya mempertimbangkan hal lain yang mampu memengaruhi volatilitas harga saham sehingga, perusahaan dapat meminimalisir tingkat volatilitas harga saham.

\section{Pengaruh Volume Perdagangan Terhadap Volatilitas Harga Saham}

Berdasarkan pengujian dengan menggunakan regresi linear berganda volume perdagangan tidak mempunyai pengaruh terhadap volatilitas harga saham perusahaan finance yang terdaftar di Bursa Efek Indonesia tahun 2014-2018. Artinya, setiap perubahan nilai volume perdagangan tidak mempunyai pengaruh dengan tingkat volatilitas harga saham. (Andiani \& Gayatri, 2018) penelitian yang sama dengan penelitian ini yaitu, nilai dari volume perdagangan saham tidak selalu dilihat oleh investor dalam melakukan investasi. Faktor harga saham yang berubah secara naik dan turun tidak dilihat dari faktor penawaran dan permintaannya saja, tetapi dapat dilihat dari tren maupun situasi yang terjadi di periode tertentu mengenai ekonomi makro yang terjadi saat itu.

Berdasarkan data perusahaan BBNI nilai volume perdagangan selama periode penelitian mengalami kenaikan maupun penurunan, volatilitas harga saham tidak mengalami perubahan yang searah dengan nilai volume perdagangan. Data tersebut menunjukkan bahwa perubahan nilai volume perdagangan belum tentu berpengaruh terhadap volatilitas harga saham.

Penelitian ini bertentangan dengan signaling theory yang menyatakan bahwa informasi mengenai tingggi rendahnya volume perdagangan berpengaruh terhadap nilai volatilitas harga saham. Tingginya volume perdagangan menggambarkan saham aktif ditransaksikan yang berarti memiliki tingkat likuiditas yang tinggi, sehingga volatilitas harga saham semakin rendah. Implikasi praktis dari penelitian yaitu, perusahaan finance tidak harus memperhatikan nilai volume perdagangan dalam mengendalikan nilai volatilitas harga saham. Perusahaan sebaiknya mempertimbangkan hal lain yang mampu memengaruhi volatilitas harga saham sehingga, perusahaan dapat meminimalisir tingkat volatilitas harga saham.

\section{KESIMPULAN}

Kesimpulan yang dapat diambil berdasarkan uraian hasil analisis yaitu dividend payout ratio dan dividend yield dapat memengaruhi volatilitas harga saham, sehingga dapat dijadikan sebagai pertimbangan dalam pengambilan keputusan dalam berinvestasi. Sedangkan variabel leverage, earning volatility, dan volume perdagangan tidak memengaruhi volatilitas harga saham, ketiga variabel tersebut sebaiknya tidak dijadikan acuan untuk mengambil keputusan saat berinvestasi.

Temuan ini diharapkan perusahaan dapat memperkecil nilai volatilitas harga sahamnya dengan mempertimbangkan nilai dividend payout ratio dan dividend yield karena besarnya jumlah pembayaran dividen dapat menarik minat investor dalam melakukan investasi di perusahaan. Selain itu, perusahaan perlu lebih baik dalam memanfaatkan asetnya agar dapat menghasilkan keuntungan yang maksimal dan dapat menekan risiko investasi sehingga harga saham akan bergerak lebih stabil. 
Ayuda Rizkya Utami \& Purwohandoko. Pengaruh Kebijakan Dividen, Leverage, Earning Volatility, dan Volume Perdagangan terhadap Volatilitas Harga Saham pada Perusahaan Sektor Finance yang Terdaftar di BEI Tahun 2014-2018

Penelitian selanjutnya diharapkan menambahkan beberapa sektor perusahaan lainnya dan memperhatikan jumlah sampel data yang akan digunakan dalam penelitian, sehingga dapat meningkatkan keakuratan hasil penelitian. Selain itu, peneliti berikutnya dapat melibatkan variabel lain diluar penelitian ini seperti inflasi, tingkat suku bunga, pertumbuhan asset dan corporate governance.

\section{DAFTAR PUSTAKA}

Ahmad, M. A., Alrjoub, A. M. S., \& Alrabba, H. M. (2018). The Effect of Dividend Policy On Stock Price Volatility: Emperical Evedence from Amman Stock Exchange. Academy of Accounting and Financial Studies Journal, 22(2).

Andes, S. L., Puspitaningtyas, Z., \& Prakoso, A. (2017). Pengaruh Inflasi, Kurs Rupiah dan Suku Bunga terhadap Return Saham Perusahaan Manufaktur. Jurnal Akuntansi Keuangan Dan Bisnis, 10(2), 8-16. http://jurnal.pcr.ac.id

Andiani, N. W. S., \& Gayatri, G. (2018). Pengaruh Volume Perdagangan Saham, Volatilitas Laba, Dividend Yield, dan Ukuran Perusahaan Pada Volatilitas Harga Saham. E-Jurnal Akuntansi, 24, 2148. https://doi.org/10.24843/eja.2018.v24.i03.p19

Ardiansyah, I., \& Isbanah, Y. (2017). analisis pengaruh dividen, pertumbuhan aset, ukuran perusahaan, dan leverage terhadap volatilitas harga saham. Jurnal Riset Akuntansi Dan Keuangan, 5(3), 1565-1573.

Azura, S. N., Sofia, M., \& Nurhasanah. (2018). Faktor - Faktor yang Mempengaruhi Volatilitas Harga Saham pada Perusahaan Manufaktur yang Tercatat di Bursa Efek Indonesia Tahun 2012-2016. 1-20.

Dewi, N. M. A. K., \& Suaryana, I. G. N. A. (2016). Pengaruh Volume Perdagangan Saham, Leverage, dan Tingkat Suku Bunga terhadap Volatilitas Harga Saham. E-Jurnal Akuntansi Universitas Udayana, 17(2), 1112-1140.

Dewi, S., \& Paramita, R. a. S. (2019). Pengaruh kebijakan dividen, volume perdagangan, earning volatility, leverage, dan firm size terhadap volatilitas harga saham perusahaan lq45. Jurnal Ilmu Manajemen, 7(3), 761-771.

Dominika, I., \& Yanti. (2019). Pengaruh Kebijakan Dividen , Leverage , Firm Size , Earning Volatility, Dan Growth Terhadap Volatilitas Harga Saham. Jurnal Multiparadigma Akuntansi, I(3), 589-598.

Fahmi, I. (2012). Manajemen Investasi: Teori dan Soal Jawab. Jakarta: Salemba Empat.

idx.co.id. (2020). Ringkasan performa perusahaan tercatat. https://www.idx.co.id/data-pasar/laporanstatistik/ringkasan-performa-perusahaan-tercatat/. Diakses 19 Maret 2020).

Ilmiyono, A. F. (2017). Pengaruh Kinerja Keuangan dan Faktor Ekonomi Makro dalam Memprediksi Volatilitas Harga Saham Subsektor Industri Food and Beverages. JIAFE (Jurnal Ilmiah Akuntansi Fakultas Ekonomi), 3(1), 35-48.

Investasi.kontan.co.id. (2018). Pasar saham masih volatil di paruh kedua 2018. https://investasi.kontan.co.id/news/pasar-saham-masih-volatil-di-paruh-kedua-2018. Diakses 6 September 2019). 
Jannah, R., \& Haridhi, M. (2016). Pengaruh Kebijakan Dividen, Earning Volatility, dan Leverage terhadap Volatilitas Harga Saham pada Perusahaan Non-Financing yang Terdaftar di Bursa Efek Indonesia Tahun 2010-2014. Jurnal Ilmiah Mahasiswa Ekonomi Akuntansi (JIMEKA), 1(1), 133-148.

Kautsar, A. (2014). Analisis Pengaruh Firm Size, Der, Dan Sales Growth terhadap Dividend Payout Ratio dengan Roe Sebagai Variabel Intervening pada Perusahaan Non Keuangan yang Listed di Bei Tahun 2009-2011. Jurnal Bisnis Strategi, 23(2), 1-13. https://doi.org/10.14710/jbs.23.2.113

Kautsar, A. (2019). Profitability is a Mediation Variable of Debt on Dividend Payout Indonesian Agriculture Companies. Scholars Journal of Economics, Business and Management, 6(2), 143146.

Khajar, I. (2016). Analisis Stock Split Terhadap Harga Saham Dan Volume Perdagangan Saham Indek Lq-45 Periode 2010 - 2016. Jurnal Keuangan Dan Perbankan, 20(3), 395-406. https://doi.org/10.26905/jkdp.v20i3.290

Kristanto, M. E., \& Idris. (2016). Analisis Pengaruh Inflasi, Kurs, Dan Suku Bunga Terhadap Pergerakan Bersama Returnsaham Ihsg Dan Volume Perdagangan Periode Januari 2006 Desember 2015. Diponegoro Journal of Management, 5(3), 1-15.

ksei.co.id. (2018). Berita Pers 21 Tahun KSEI: Inovasi Untuk Kenyamanan Transaksi di Pasar Modal. Ksei.Co.Id. https://www.ksei.co.id/files/uploads/press_releases/press_file/idid/156_berita_pers_21_tahun_ksei_inovasi_untuk_kenyamanan_transaksi_di_pasar_modal_201 90111170001.pdf. Diakses 7 September 2019).

Kurniasih, S., \& Surachim, A. (2018). Debt to Equity Ratio (DER) dan Return On Asset (ROA) untuk Meningkatkan Harga Saham. Strategic: Jurnal Pendidikan Manajemen Bisnis, 18(2), 44-52. https://doi.org/10.17509/strategic.v18i2.17590

Lestari, R. M. ., \& Permatasari, P. (2016). Studi Terhadap Pembagian Dividen Dan Dampaknya Terhadap Harga Saham Perusahaan-Perusahaan Yang Terdaftar Di Bursa Efek Indonesia Periode 2011-2014. JIAFE (Jurnal Ilmiah Akuntansi Fakultas Ekonomi), 2(1), 69-85.

Mobarak, R., \& Mahfud. (2017). Analisis Pengaruh Kebijakan Dividen, BVPS, Earning Volatility, Leverage, PER, dan Volume Perdagangan Terhadap Volatilitas Harga Saham. Diponegoro Journal of Management, 6(2), 1-13.

Mulyaningsih, N., \& Rahayu, D. (2016). Pengaruh Laba Bersih Dan Arus Kas Operasi Terhadap Kebijakan Dividen Pada Perusahaan Food and Beverage Yang Terdaftar Di Bursa Efek Indonesia. Dharma Ekonomi, 23(43), 33-43.

Nuswandari, C. (2009). Pengungkapan Pelaporan Keuangan Dalam Perspektif Signalling Theory. Kajian Akuntansi, 1(1), 48-57.

Priana, I. W. K., \& Muliartha, K. (2017). Pengaruh Volume Perdagangan Saham, Leverage, Dan Dividend Payout Ratio Pada Volatilitas Harga Saham. Jurnal Akuntansi Universitas Udayana, 20(1), 1-29.

Purwohandoko, Asandimitra, N., Isbanah, Y., \& Kautsar, A. (2014). Dasar-dasar Manajemen Keuangan. Teori, Aplikasi, dan Kasus. Surabaya: Unesa University Press.

Rahayu, T. N., \& Masud, M. (2019). Pengaruh Tingkat Suku Bunga, Nilai Tukar Rupiah dan Volume Perdagangan Saham Terhadap Harga Saham Perusahaaan Manufaktur. Jurnal Ilmu Ekonomi 
Ayuda Rizkya Utami \& Purwohandoko. Pengaruh Kebijakan Dividen, Leverage, Earning Volatility, dan Volume Perdagangan terhadap Volatilitas Harga Saham pada Perusahaan Sektor Finance yang Terdaftar di BEI Tahun 2014-2018

Paradoks, 2(2).

Rohmawati, I. (2017). Pengaruh Volume Perdagangan, Dividend Payout Ratio Dan Inflasi Terhadap Volatilitas Harga Saham Pada Perusahaan Yang Terdaftar Dalam Indeks LQ45 Tahun 20112015. Jurnal Pendidikan Dan Ekonomi, 6(1).

Rowena, J., \& Hendra. (2017). Earnings Volatility, Kebijakan Dividen , Dan Pertumbuhan Asset Berpengaruh Terhadap Volatilitas Harga Saham Pada Perusahaan Manufaktur Di BEI Periode 2013 - 2015. Jurnal Administrasi Kantor, 5(2), 231-242.

Selpiana, K. R., \& Badjra, I. B. (2018). Pengaruh Kebijakan Dividen, Nilai Tukar, Leverage, dan Firm Size terhadap Volatilitas Harga Saham. E-Jurnal Manajemen Universitas Udayana, 7(3), 1682. https://doi.org/10.24843/ejmunud.2018.v7.i03.p20

Sova, M. (2013). Pengaruh Ratio Leverage Terhadap Volatilitas Saham Pada Industri Barang Konsumsi Di Bursa Efek Indonesia Tahun 2004-2008. E-Journal WIDYA Ekonomi, 1.

Surahmat, Swandari, F., \& Dewi, D. M. (2017). Pengaruh kebijakan dividen dan faktor lainnya terhadap volatilitas harga saham perusahaan pertambangan. Jurnal Wawasan Manajemen, 05.

Tandelilin, E. (2010). Analisis Investasi dan Manajemen Portofolio. Yogyakarta: Kanisius.

Theresia, P., \& Arilyn, erika jimena. (2015). Pengaruh Dividen, Ukuran Perusahaan , Hutang Jangka Panjang, Earning Volatility, Pertumbuhan Aset, Trading Volume, Dan Kepemilikan Manajerial Terhadap Volatilitas Harga Saham. Jurnal Bisnis Dan Akuntansi, 17(2), 197-204.

Ullah, H., Saqib, shahab e, \& Usman, H. (2015). The Impact of Dividend Policy on Stock Price Volatility: A Case Study of Selected Firms from Textile Industry in. International Journal of Academic Research in Economics and Management Sciences, 4(3), 40-51. https://doi.org/10.6007/IJAREMS/v4-i3/2033 